\title{
Chromosome protection scoops Nobel
}

\section{ノ一ベル医学生理学賞は、染色体の保護機構 テロメアの解明に}

Alison Abbott Nature Vol. 461(706-707)/ 8 October 2009

2009 年度の医学生理学賞は、染色体の末端にあるテロメアの役割を明らかにした研究者 3 氏に決定した。

2009 年度のノーベル医学生理学賞は、 染色体末端にあるテロメアとよばれる キャップ構造を発見し、この構造によって 染色体が分解から保護される仕組みを解 明した、3人の米国の研究者に贈られる。 1980 年代から 1990 年代にかけて細胞 生物学の分野でなされたこの発見によっ て、老化やがんの研究に新たな道が開か れ、いまなお、この分野では活発な研究 が展開されている。

10 月 5 日に発表された受賞者は、カ リフォルニア大学サンフランシスコ校の Elizabeth Blackburn、メリーランド州バ ルチモアにあるジョンズホプキンス大学医 学系大学院の Carol Greider、マサチュー セッツ州ボストンにあるハーバード大学医 学系大学院の Jack Szostak の 3 人で、賞 金は等分される。既に3人はこの業績に 対してさまざまな賞を受賞しており、ノー ベル賞の先取り賞とも見なされることの多 いラスカー賞を、2006 年度に共同受賞し ている。

彼らの研究によって、染色体内に格納 されているDNAが、細胞分裂中にDNA ポリメラーゼ酵素によって、欠けることな くすべて複製されるための根本的な仕組 みの 1 つが明らかになった。染色体の末 端部にはテロメアとよばれるキャップ構造 があり、以前からこの構造は保護的な機 能をもつとみられていた（次ページの図 を参照)。テロメアがないと、染色体は細 胞分裂のたびに短くなってしまうと考えら れた。というのは、DNA ポリメラーゼは

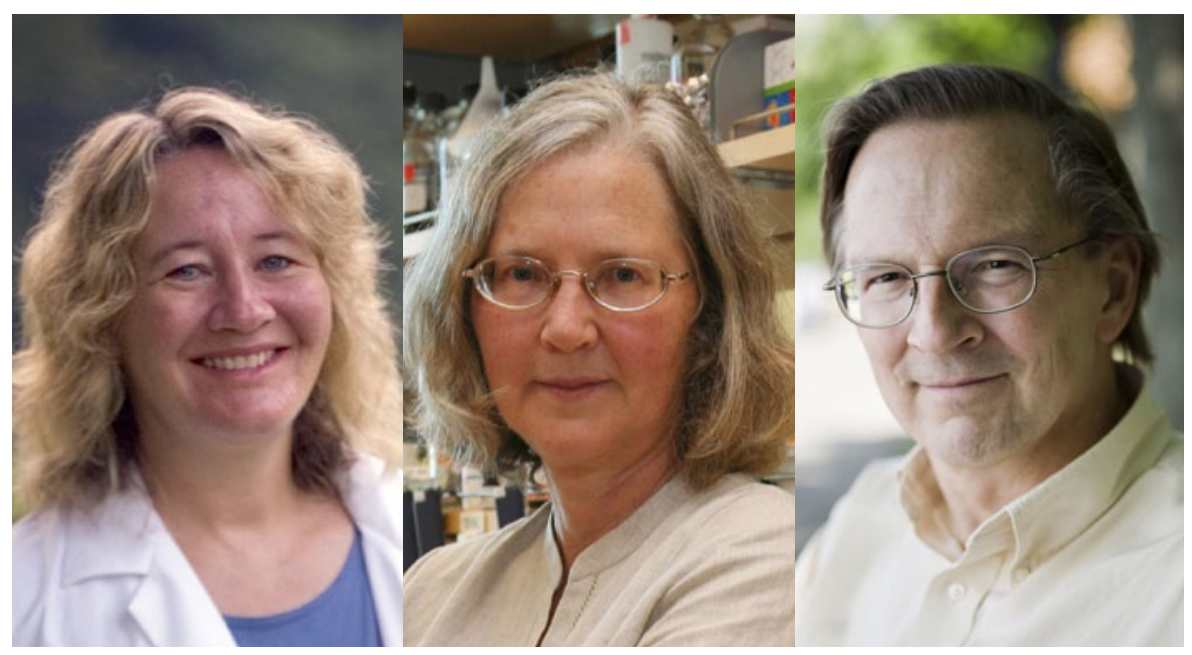

共同受賞の 3 氏。左から Carol Greider、Elizabeth Blackburn、Jack Szostak。

その性質上、複製対象とするDNA の最末 端の部分を複製できないからである。

\section{種を越えた作用}

Blackburn とSzostak は 1980 年に開催 されたゴードン研究会議で偶然出会い、 その後共同研究を始めた。そして 1980 年代初め、テロメアに特定の DNA 配列が 含まれていることを見つけた。2人はお互 いの研究の目新しさに触発されて実験を いくつか考え出したが、それらは当時か なり奇抜な実験と見なされ、彼ら自身も またそう思っていたようである。Szostak は、Blackburn が原生動物のテトラヒメ ナ Tetrahymena thermophilaで見つけたテ ロメア配列に着目し、これをミニ染色体に 連結させて、彼のお気に入りのモデル生 物だった酵母に入れてみた。
すると、テロメア配列のおかげで、異 種細胞内に入れたこれらの染色体は保護 されたのである ${ }^{1}$ 。やがて、テロメアによ るこの保護作用は、ほぼすべての動植物 に存在する基本的な生体機構の 1 つであ ることが明らかになった。さらに Szostak と Blackburnは、この機構には未知の 酵素が関与しているに違いないとにらん だ。1984 年のクリスマスの日、当時大学 院で Blackburn の下にいた Greider は、 Blackburn と 2 人で「テロメラーゼ」と 名付けたこの酵素が、実際にテロメアの DNA 修復を担っていることを示す証拠を 初めて見つけたのだった 2 。

彼女たちは、DNA ポリメラーゼが染色 体の末端部を失うことなく全長を複製する うえで、テロメラーゼが基盤機構の重要 な一端を担っていることを明らかにした。 
2 人はさらに、テロメラーゼにはテロメア DNA の鋳型になる重要な RNA 配列が含 まれていることも示した ${ }^{3}$ 。こうしてでき あがったテロメア DNA にタンパク質が集 まって結合し、DNA 鎖の末端部に保護用 のキャップ構造が形成されるわけだ。

テロメア自体は細胞分裂を繰り返すうち に短くなっていくため、細胞の老化機構の 重要な要因となっている。テロメラーゼの 活性低下やテロメアの短縮によって老化は スピードアップする。一方、際限なく分裂 するがん細胞ではテロメラーゼ活性が高 く、テロメアの長さが維持されている場合 が多い。現在、テロメラーゼを標的とする がん治療法の臨床試験が複数進行中だ。

ただし、今後解明すべき生物学上の基 本的問題もまだ多数残っている。例えば、 テロメラーゼ活性は個々のテロメアでどの ように制御されているのだろうか。また、 DNA 修復酵素は DNA のほころびを探し 回って見つけ出し、切れた DNA の両端を つなぎ合わせるが、テロメアはどうやって こうした酵素を引き寄せずにすんでいるの だろうか。

\section{女性科学者の独壇場}

Blackburn と Greider は、1901 年に創 設されたノーベル医学生理学賞の女性受 賞者としてはまだ 9 人目と 10 人目であり、 1 つの賞で女性 2 人が共同受賞したのは 今回が初めてである。実際のところ、テロ メア研究者には不思議なほど女性が多い。 「男性を見つけるのが難しいくらいです ね。その主な 2 つ原因は Liz (Greider) と Carol (Blackburn)にあります。何といっ ても、この分野を作り上げたのは彼女た ちですし、研究者のお手本にもなっている のですから」と、ジュネーブ大学（スイス） の細胞生物学者 David Shore は指摘する。 Blackburn は米国の科学政策にもか かわったことがあり、2002 年に大統領 諮問機関である生命倫理委員会の委員と なったが、当時のジョージ・W・ブッシュ 大統領がヒト胚性幹細胞（ES 細胞）研 究を規制したことを批判して、2004 年 に解任された。

Greider が指導した最初の大学院生で、 現在はエディンバラ大学ウェルカムトラ ス卜細胞生物学センター（英国）にいる
染色体のキャップ構造

テロメアは染色体の末端部を保護するキャップ構 造を形成しており、酵素テロメラーゼが作る DNA 反復配列からできている。

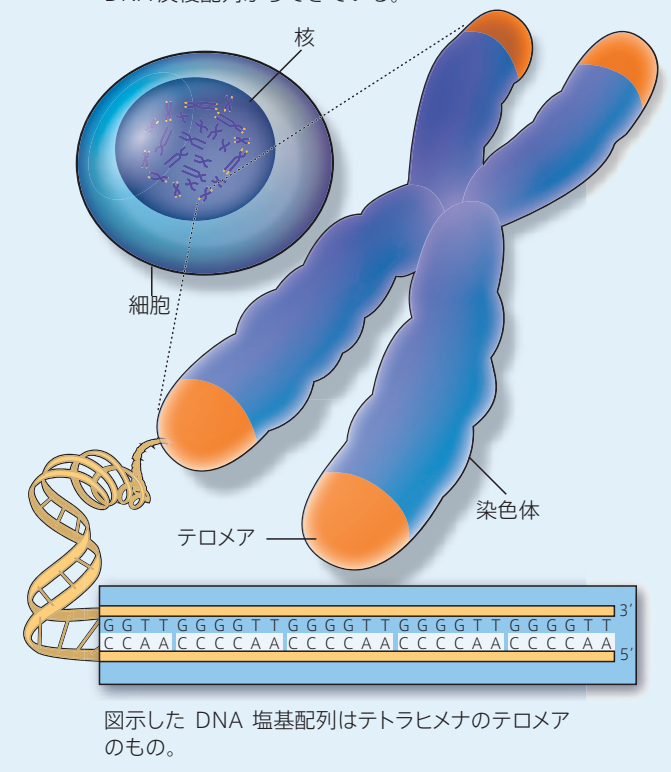

Lea Harrington は、彼女自身がニューヨー クのコールド・スプリング・ハーバー研究 所の Greider 研究室で過ごしたころを振り 返り、こう語ってくれた。「あの 4 年間は 本当に刺激的でした。活気に満ちた時代 のさなかにいることを、そこにいる全員が 実感していました。テロメラーゼの構成や 働く仕組みやヒトの生物学との関連性に ついて、疑問が次々とあ小れ出てきた時 でしたから」。(船田晶子 訳) 